\title{
Tarımsal Üretim İçin Entegre Kaynak Verimliliği
}

\author{
Nusret Mutlu ${ }^{1 *}$ \\ 1* GAP Bölge Kalkınma İdaresi Başkanlı̆̆ı, Şanlıurfa, Türkiye, (ORCID: 0000-0002-5780-4152), nmutlu@gap.gov.tr
}

(İlk Geliş Tarihi 20 Ağustos 2020 ve Kabul Tarihi 13 Ekim 2020)

(DOI: $10.31590 /$ ejosat.782364)

ATIF/REFERENCE: Mutlu, N. (2020). Tarımsal Üretim İçin Entegre Kaynak Verimliliği. Avrupa Bilim ve Teknoloji Dergisi, (20), 293-298.

\section{$\ddot{\mathbf{O z}}$}

Tarımsal üretimde, yakıt ve elektrik tüketilerek doğrudan ve tarım makineleri, gübreler ve tarım ilaçlarının üretimi süreçlerinde enerji tüketimi nedeniyle dolaylı olarak enerji kullanılır. Farklı ortamlardaki farklı üretim sistemleri, enerji kullanımı ve enerji tasarrufu potansiyellerine göre büyük ölçüde farklılık gösterir. Bu çalışmada, sürdürülebilir tarımsal üretim için entegre kaynak verimliliği değerlendirilmiştir. Tarımsa üretimde sürdürülebilik için, bazı teknik, ekonomik ve çevresel ölçütler tanımlanmıştır. Tarımsal üretimde enerji verimliliği sağlamak için gerekli olan enerji tasarrufu uygulamaları üretim sürecinde kullanılan sistemlere, işletimsel uygulamalara ve üretime giren sermaye malları / çiftlik altyapısına uygulandığı zaman önemli bir katkı sağlayacaktır.

Anahtar Kelimeler: Tarımsal üretim, Kaynak verimliliği, Sürdürülebilir tarım.

\section{Integrated Resource Management for Sustainable Agricultural Production}

\begin{abstract}
In agricultural production, energy is used directly by consuming fuel and electricity and indirectly due to energy consumption in the production of agricultural machinery, fertilizers and pesticides. Different production systems in different environments differ greatly in their energy use and energy saving potential. In this study, integrated resource efficiency for sustainable agricultural production is evaluated. Integrated resource efficiency for sustainable agricultural production has been evaluated. In agriculture, some technical, economic and environmental criteria are defined for sustainability in production. Energy saving measures will be particularly important for achieving energy efficiency in agriculture when applied to systems involved in the production process, operational practices and capital goods / farm infrastructure entering production.
\end{abstract}

Keywords: Agriculture, Resource efficiency, Resource management, Sustainability.

*Sorumlu Yazar: nmutlu@gap.gov.tr 


\section{Giriş}

Enerji verimliliği, ürün ve hizmet sunmak için gereken enerji miktarını azaltma çabalarının hedefidir. Tarla bitkileri için ana enerji girdisi, gübre ve dizel yakıt kullanımı ile ilişkilidir. Genellikle sulama, kurutma ve/veya depolama uygulamalarında enerji tüketimi önemlidir.

Bu uygulamalar için tüketilen enerji miktarı; coğrafi konuma ve ilgili iklime ve üretim sistemlerinin özelliklerine bağlıdır. Orta ve Kuzey $A B$ ülkelerinde, seralarda sebze üretimi için, fazla miktarda doğrudan enerji kullanımı gerçekleşmektedir. $\mathrm{Bu}$ durum, Güney $\mathrm{AB}$ ülkelerindeki örtü altı üretim sisteminden önemli ölçüde farklıdır. Güney ülkelerinde örtü altında yetiştirilen ürünler, doğrudan toprakta yetiştirildiklerinde, çok azdır.

Bununla birlikte, topraksız tarım sistemlerde daha yüksek enerji girdisi gereklidir. Zeytin üretimi için özgül enerji tüketimi, güneybatı Avrupa ülkelerinde, güneydoğu Avrupa ülkelerinden daha yüksektir. (agrEE (2012a). Bu ülkelerde, süt ineği yetiştiriciliği ve etlik piliç üretiminde, yem tüketimi nedeniyle çok fazla miktarda enerji tüketilmektedir.

Tarımsal üretimde, büyük ölçüde yakıt veya elektrik olarak doğrudan ve tarım makineleri, gübreler veya tarım ilaçlarının üretimi süreçlerinde enerji tüketimi nedeniyle dolaylı olarak enerji kullanılır. Tarımda enerji kullanımı konusundaki değerlendirmeler genellikle doğrudan enerji kullanımına odaklanırken, toplam enerji kullanımının \% 50 ve daha fazlasının azotlu gübre üretimi enerjisi ve diğer dolaylı enerji kullanımları ile ilgili olduğu kabul edilmelidir (Woods ve Ark. 2010; Pelletier ve Ark., 2011).

Farklı ortamlardaki farklı üretim sistemleri, enerji kullanımı ve enerji tasarrufu potansiyellerine göre büyük ölçüde farklılık gösterir. Tarımsal üretimde enerji kullanımı konusunda kapsamlı araştırmalar yapılmaktadır (Baran ve Ark., 2019a; 2019b; Baran ve Gökdoğan, 2020; Yıldızhan, 2019). Bu çalışmada, sürdürülebilir tarımsal üretim için entegre kaynak verimliliği değerlendirilmiştir.

\section{Materyal ve Metot}

\subsection{Enerji Girdilerinin Belirlenmesi}

Tarımda enerji kullanımı hem doğrudan enerji kullanımını hem de tarım ürünleri üretmek için kullanılan her türlü girdiyle ilişkili dolaylı enerji kullanımını kapsar. Enerji giderlerinin belirlenmesinde, yaşam döngüsü değerlendirmesine (LCA) benzer bir yaklaşım kabul edilir.

Enerji kullanımı ilişkin değerler, ortalama üretim rakamlarına veya en iyi tahminlere dayanarak oluşturulur. Her bir alt üretim grubu için, birincil enerji tüketimi (BET) ve fosil enerji tüketimi değerleri (FET) dikkate alınır.

Girdi olarak kullanılan fiziksel değerler, belirli katsayılar kullanılarak enerji değerlerine dönüştürülmüştür (Tablo 1. Bir tarımsal üretim sürecinde kullanılan girdiler ve uygulanan teknolojiler dikkate alınarak; düşük, orta ve yüksek girdi kullanılan sistemler olarak değerlendirilmektedir.

Tarımsal üretim süreçlerinde enerji kullanımının belirlenmesi için dikkate alınan başlıca girdiler Tablo 1'de verilmiştir.

\subsubsection{Doğrudan Enerji Kullanımının Belirlenmesi}

Doğrudan enerji girdileri; elektrik, rafine edilmiş petrol ürünleri (dizel, doğal gaz ve diğerleri), doğal gaz bazlı yakıtlar ve talaş dahil olmak üzere tarımsal üretim sürecinde doğrudan kullanılan tüm enerji kaynakları ve enerji taşıyıcıları kapsar.

> Elektrik: Tüketilen kWh elektrik miktarı MJ enerji birimine dönüştürülür. Aydınlatma, elektrikli ekipman, otomasyon süreçleri ve çiftlik yönetiminde tüketilen toplam elektrik miktarı.

> Rafine petrol yakıtları: Tüketilen litre (L) yakıt miktarı MJ enerji birimine dönüştürülür.

> Doğal gaz ve sıvı propan: Ürün kurutucularda 1S1 kaynağı, güç makinelerinde ve seralarda 1sı ve güç ünitelerinde yakıt olarak kullanılır.

> Biyokütle ve katı yakıtlar: Sera ve hayvan barınakları gibi çiftlik 1sı ihtiyacının karşılanması için kullanılır.

\subsubsection{Dolaylı Enerji Kullanımının Belirlenmesi}

Dolaylı enerji girdileri; kimyasal gübreler, tarım ilaçları, tarım alet ve makinaları, sera ve hayvan barınakları gibi tarımsal yapıların yanı sıra, tohum ve yem gibi tarımsal üretim girdilerinin üretiminde tüketilen enerjiyi içerir.

Besin ve temel g1da hammaddelerinin üretiminde enerji verimliliğinin belirlenmesinde, hayvansal üretim için; yem ve özel yem takviyelerinin, bitkisel üretim için; tohumlar, inorganik gübreler, tarım ilaçları ve tarımsal mekanizasyon araçlarının üretim süreçlerinde tüketilen dolaylı enerji girdileri dikkate alınır.

Bitkisel üretimde kullanılan kimyasal gübre ve tarım ilaçlarının üretiminde önemli miktarda enerji tüketilmektedir. Enerji verimliliği göstergesi olarak aşağıdaki iki temel ölçüt dikkate alınmaktadır:

1)Tarımsal üretimde kullanılan birim üretim alanı (ha) başına enerji (GJ) kullanım oranı (GJ/ha)

2) Tarımsal üretim sonucunda üretilen birim ürün (t) başına ener enerji (GJ) kullanım oranı $(\mathrm{GJ} / \mathrm{t})$

Enerji verimliliği göstergeleri aşağıdaki girdi gruplarını kapsamaktadır:

1) Doğrudan Enerji Girdileri: Tarımsal üretim işlemleri süreçlerinde tüketilen elektrik ve katı, sıvı ve gaz yakıtların toplamı olarak dikkate alınır ve fosil enerji kullanımı olarak değerlendirilir (GJ/ha, GJ/L)

2) Dolaylı Enerji Girdileri: Tarımsal üretim süreçlerinde kullanılan kaynakların üretimi için fabrikalarda tüketilen enerjiler olarak dikkate alınır (GJ/ha, GJ/L)

3) Toplam Enerji Girdileri: Tarımsal üretimde birim üretim alanında kullanılan doğrudan ve dolaylı enerji girdilerinin toplamıdır (GJ/ha, GJ/L)

4) Özgül Enerji Girdisi: Tarımsal üretim yapılan birim tarım alanı için $(\mathrm{GJ} / \mathrm{ha})$ veya üretim sonucunda üretilen bir ton tarımsal ürün $(\mathrm{GJ} / \mathrm{t})$ için, tarımsal üretim süreçlerinde toplam birincil enerji kullanımıdır. 
Tablo 1. Tarımsal Üretimde Doğrudan ve Dolaylı Enerji Girdileri İçin Dönüşüm Katsayıları (agrEE, 2012a, 2012b)

\begin{tabular}{|c|c|c|c|}
\hline \multirow{2}{*}{ Enerji Girdileri } & \multirow{3}{*}{ Birimler } & \multicolumn{2}{|c|}{ Enerji Değerleri } \\
\hline & & \multirow{2}{*}{ FET } & \multirow{2}{*}{ BET } \\
\hline Doğrudan Enerji Girdileri & & & \\
\hline Elektrik & $\mathrm{MJ} / \mathrm{kWh}$ & 3.60 & 9.70 \\
\hline Dizel & $\mathrm{MJ} / \mathrm{kg}$ & 43.10 & 50.00 \\
\hline Doğal gaz & $\mathrm{MJ} / \mathrm{m}^{3}$ & 31.60 & 35.70 \\
\hline Odun talaşı & $\mathrm{MJ} / \mathrm{kg}(\mathrm{MC} \%$ 30) & 12.40 & 12.40 \\
\hline \multicolumn{4}{|l|}{ Dolaylı Enerji Girdileri } \\
\hline Tohum- Tahıl & $\mathrm{MJ} / \mathrm{kg}$ & 2.61 & 2.61 \\
\hline Tohum- Şekerpancarl & $\mathrm{MJ} / \mathrm{kg}$ & 36.29 & 36.29 \\
\hline Tohum-Yumrular & $\mathrm{MJ} / \mathrm{kg}$ & 1.05 & 1.05 \\
\hline Tohum-Pamuk & $\mathrm{MJ} / \mathrm{kg}$ & 52.60 & 52.60 \\
\hline \multicolumn{4}{|l|}{ Kimyasal Gübreler } \\
\hline $\operatorname{Azot}(N)$ & $\mathrm{MJ} / \mathrm{kg}$ & 48.99 & 48.99 \\
\hline Fosfor $\left(\mathrm{P}_{2} \mathrm{O}_{3}\right)$ & $\mathrm{MJ} / \mathrm{kg}$ & 15.03 & 15.03 \\
\hline Potasyum $\left(\mathrm{K}_{2} \mathrm{O}\right)$ & $\mathrm{MJ} / \mathrm{kg}$ & 9.68 & 9.68 \\
\hline Kalsiyum (CaO) & $\mathrm{MJ} / \mathrm{kg}$ & 1.97 & 1.97 \\
\hline Magnezyum $(\mathrm{MgO})$ & $\mathrm{MJ} / \mathrm{kg}$ & 6.70 & 6.70 \\
\hline Kükürt (S) & $\mathrm{MJ} / \mathrm{kg}$ & 2.10 & 2.10 \\
\hline \multicolumn{4}{|l|}{ Tarım İlaçları (Pestisitler) } \\
\hline Herbisitler & $\mathrm{MJ} / \mathrm{kg}_{\text {etkili madde }}$ & 268.4 & 268.4 \\
\hline Fungusitler & $\mathrm{MJ} / \mathrm{kg}_{\text {etkili madde }}$ & 268.4 & 268.4 \\
\hline Insektisitler & $\mathrm{MJ} / \mathrm{kg}_{\text {etkili madde }}$ & 268.4 & 268.4 \\
\hline Nemotositler & $\mathrm{MJ} / \mathrm{kg}_{\text {etkili madde }}$ & 268.4 & 268.4 \\
\hline \multicolumn{4}{|l|}{ Diğer Üretim Girdileri } \\
\hline Organik & $\mathrm{MJ} / \mathrm{kg}$ & 0.30 & 0.30 \\
\hline $\mathrm{Su}$ & $\mathrm{MJ} / \mathrm{m}^{3}$ & 0.63 & 0.63 \\
\hline $\mathrm{Bez}$ & $\mathrm{MJ} / \mathrm{m}^{2}$ & 81.00 & 81.00 \\
\hline Sera substratı & $\mathrm{MJ} / \mathrm{m}^{2}$ & 13.00 & 13.00 \\
\hline Serada el ile çalışma & $\mathrm{MJ} / \mathrm{h}$ & 40.00 & 40.00 \\
\hline Serada usı perdeleri & $\mathrm{MJ} / \mathrm{m}^{2}$ & 41.00 & 41.00 \\
\hline Serada solarizasyon filmi & $\mathrm{MJ} / \mathrm{m}^{2}$ & 170.00 & 170.00 \\
\hline Sera plastik örtü malzemesi (LDPE) & $\mathrm{MJ} / \mathrm{m}^{2}$ & 69.50 & 69.50 \\
\hline \multicolumn{4}{|l|}{ Çiftlik Hayvanları ${ }^{1}$} \\
\hline Silaj, $M C \% 70$ & $\mathrm{MJ} / \mathrm{kg}_{\mathrm{DM}}$ & 0.90 & 0.90 \\
\hline Otlaktan yem, $M C \% 70$ & $\mathrm{MJ} / \mathrm{kg}_{\mathrm{DM}}$ & 0.50 & 0.50 \\
\hline Kuru saman, $M C \% 15$ & $\mathrm{MJ} / \mathrm{kg}_{\mathrm{DM}}$ & 1.90 & 1.90 \\
\hline Kesif yem (tahil), MC\% 40 & $\mathrm{MJ} / \mathrm{kg}_{\mathrm{DM}}$ & 3.60 & 3.60 \\
\hline Karma yem, $M C \% 12$ & $\mathrm{MJ} / \mathrm{kg}_{\mathrm{DM}}$ & 3.80 & 3.80 \\
\hline Protein konsantresi, $M C \% 12$ & $\mathrm{MJ} / \mathrm{kg}_{\mathrm{DM}}$ & 3.90 & 3.90 \\
\hline Yarım konsantre, $M C \% 12$ & $\mathrm{MJ} / \mathrm{kg}_{\mathrm{DM}}$ & 3.90 & 3.90 \\
\hline Endüstriyel yem, $M C \% 12$ & $\mathrm{MJ} / \mathrm{kg}_{\mathrm{DM}}$ & 4.20 & 4.20 \\
\hline Soya fasulyesi & $\mathrm{MJ} / \mathrm{kg}_{\mathrm{DM}}$ & 4.25 & 4.25 \\
\hline Kolza tohumu & $\mathrm{MJ} / \mathrm{kg}_{\mathrm{DM}}$ & 5.26 & 5.26 \\
\hline Tritikale & $\mathrm{MJ} / \mathrm{kg}_{\mathrm{DM}}$ & 3.89 & 3.89 \\
\hline Saman, Talaş (yataklık) & $\mathrm{MJ} / \mathrm{kg}_{\mathrm{DM}}$ & 1.80 & 1.80 \\
\hline $\mathrm{Su}$ & $\mathrm{MJ} / \mathrm{m}^{3}$ & 0.63 & 0.63 \\
\hline Binalar & $\mathrm{MJ} / \mathrm{m}^{2}$ & 153.00 & 153.00 \\
\hline
\end{tabular}




\subsection{Tarımsal Üretimde Sürdürülebilirlik Göstergeleri}

Bu çalışmada, tanımlanmış olan tarımsal üretimde ekonomik üretim, enerji tüketimi ve çevresel etkiler için sürdürülebilirlik göstergeleri Tablo 2'de verilmiştir.

\section{Tablo 2. Tarımsal Üretimde Sürdürülebilirlik Göstergeleri}

\begin{tabular}{|c|c|c|c|c|}
\hline & Gösterge Adı & Tanımlama & Birim Analizi & Birim \\
\hline \multirow{8}{*}{ 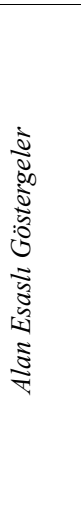 } & Maliyet göstergesi & $\begin{array}{l}\text { Tarımsal üretim işlemleri için kullanılan sabit ve değişken özellikteki bütün } \\
\text { girdilerin toplam parasal değerinin, üretim yapılan tarım alanına oranıdır. }\end{array}$ & Maliyet/Alan & TL/ha \\
\hline & Yakut göstergesi & $\begin{array}{l}\text { Tarımsal üretim işlemlerinde kütle veya hacim olarak tüketilen yakıt miktarının, } \\
\text { üretim yapılan tarım alanına oranıdır. }\end{array}$ & Kütle (Hacim)/Alan & $\mathrm{kg}(\mathrm{L}) / \mathrm{ha}$ \\
\hline & Enerji göstergesi & $\begin{array}{l}\text { Tarımsal üretim işlemlerinde tüketilen toplam enerji miktarının, üretim yapılan } \\
\text { tarım alanına oranıdır. }\end{array}$ & Enerji/Alan & $\mathrm{MJ} / \mathrm{ha}$ \\
\hline & Enerji verimi & $\begin{array}{l}\text { Tarımsal üretim sonucunda elde edilen ürünün toplam enerji içeriğinden, üretim } \\
\text { için tüketilen toplam enerji miktarı çıkarılarak belirlenir. }\end{array}$ & $\begin{array}{l}\text { (Enerji/Alan)/ } \\
\text { (Enerji/Alan) }\end{array}$ & $\mathrm{MJ} / \mathrm{ha}$ \\
\hline & $\begin{array}{l}\text { Toplam sera gazl } \\
\text { emisyonu göstergesi }\end{array}$ & $\begin{array}{l}\text { Tarımsal üretim işlemlerinde enerji tüketimi sonucunda gerçekleşen sera gazı } \\
\text { emisyonlarının toplam miktarının, üretim yapılan tarım alanına oranıdır. }\end{array}$ & Kütle/Alan & $\mathrm{kg}_{\mathrm{CO} 2} / \mathrm{ha}$ \\
\hline & $\mathrm{CO}_{2}$ göstergesi & $\begin{array}{l}\text { Tarımsal üretim işlemlerinde enerji tüketimi sonucunda gerçekleşen } \mathrm{CO}_{2} \\
\text { emisyonlarının toplam miktarının, üretim yapılan tarım alanına oranıdır. }\end{array}$ & Kütle/Alan & $\mathrm{kg}_{\mathrm{CO} 2} / \mathrm{ha}$ \\
\hline & $\mathrm{NO}_{2}$ göstergesi & $\begin{array}{l}\text { Tarımsal üretim işlemlerinde enerji tüketimi sonucunda gerçekleşen } \mathrm{NO}_{2} \\
\text { emisyonlarının toplam miktarının, üretim yapılan tarım alanına oranıdır. }\end{array}$ & Kütle/Alan & $\mathrm{kg}_{\mathrm{NO} 2} / \mathrm{ha}$ \\
\hline & $\mathrm{SO}_{2}$ göstergesi & $\begin{array}{l}\text { Tarımsal üretim işlemlerinde enerji tüketimi sonucunda gerçekleşen } \mathrm{SO}_{2} \\
\text { emisyonlarının toplam miktarının, üretim yapılan tarım alanına oranıdır. }\end{array}$ & Kütle/Alan & $\mathrm{kg}_{\mathrm{SO} 2} / \mathrm{ha}$ \\
\hline \multirow{3}{*}{ 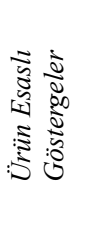 } & Yakut göstergesi & $\begin{array}{l}\text { Tarımsal üretim işlemlerinde kütle veya hacim olarak tüketilen yakıt miktarının, } \\
\text { üretim sonucunda elde edilen ürünün kütlesel veya hacimsel miktarına oranıdır. }\end{array}$ & $\begin{array}{l}\text { Kütle } \\
\text { (Hacim)/Kütle(Hacim) }\end{array}$ & $\mathrm{kg}(\mathrm{L}) / \mathrm{kg}(\mathrm{L})_{\text {ürün }}$ \\
\hline & Enerji göstergesi & $\begin{array}{l}\text { Tarımsal üretim işlemlerinde tüketilen enerji miktarının, üretim sonucunda elde } \\
\text { edilen ürünün kütlesel veya hacimsel miktarına oranıdır. }\end{array}$ & Enerji/Kütle (Hacim) & $\mathrm{MJ} / \mathrm{kg}(\mathrm{L})_{\text {ürün }}$ \\
\hline & $\begin{array}{l}\text { Emisyon } \\
\text { göstergesi }\end{array}$ & $\begin{array}{l}\text { Tarımsal üretim işlemlerinde enerji tüketimi sonucunda gerçekleşen sera gazı } \\
\text { emisyonlarının toplam miktarının, üretim sonucunda elde edilen toplam ürün } \\
\text { miktarına oranıdır. }\end{array}$ & Kütle/Kütle & $\mathrm{kg}_{\mathrm{CO} 2} / \mathrm{kg}(\mathrm{L})_{\text {ürün }}$ \\
\hline \multirow{4}{*}{ 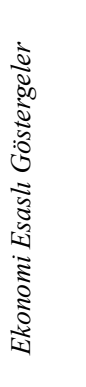 } & Özgül maliyet & $\begin{array}{l}\text { Tarımsal üretim işlemleri için kullanılan sabit ve değişken özellikteki bütün } \\
\text { girdilerin toplam parasal değerinin, üretim sonucunda elde edilen ürünün kütlesel } \\
\text { veya hacimsel miktarına oranıdır. }\end{array}$ & Maliyet/Kütle (Hacim) & $\mathrm{TL} / \mathrm{kg}(\mathrm{L})_{\text {ürün }}$ \\
\hline & $\begin{array}{l}\text { Ekonomik } \\
\text { üretkenlik }\end{array}$ & $\begin{array}{l}\text { Tarımsal üretim sonucunda elde edilen ürünün kütlesel veya hacimsel miktarının, } \\
\text { üretim işlemleri için kullanılan sabit ve değişken özellikteki bütün girdilerin toplam } \\
\text { parasal değerine oranıdır. }\end{array}$ & Kütle (Hacim)/Maliyet & $\operatorname{kg}(\mathrm{L})_{\text {ürün }} / \mathrm{TL}$ \\
\hline & $\begin{array}{l}\text { Ekonomik } \\
\text { verimlilik oranı }\end{array}$ & $\begin{array}{l}\text { Tarımsal üretim sonucunda elde edilen toplam gelirin parasal değerinin, üretim } \\
\text { işlemleri için kullanılan sabit ve değişken özellikteki bütün girdilerin toplam } \\
\text { parasal değerine oranıdır. }\end{array}$ & Maliyet/Maliyet & TL/TL \\
\hline & Net karlılık & $\begin{array}{l}\text { Tarımsal üretim sonucunda elde edilen toplam gelirin parasal değeri ile üretim } \\
\text { işlemleri için kullanılan sabit ve değişken özellikteki bütün girdilerin parasal değeri } \\
\text { arasındaki farktır. }\end{array}$ & Para-Para & $\mathrm{TL}$ \\
\hline \multirow{3}{*}{ 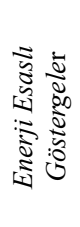 } & Yakıt göstergesi & $\begin{array}{l}\text { Tarımsal üretim sonucunda elde edilen ürünün kütlesel veya hacimsel miktarının, } \\
\text { üretim ișlemlerinde kütle veya hacim olarak tüketilen yakıt miktarına oranıdır. }\end{array}$ & $\begin{array}{l}\text { Kütle (Hacim) / Kütle } \\
\text { (Hacim) }\end{array}$ & $y(\mathrm{~L})_{\text {ürün }} / \mathrm{kg}(\mathrm{L})_{\text {yakıt }}$ \\
\hline & Enerji göstergesi & $\begin{array}{l}\text { Tarımsal üretim sonucunda elde edilen ürünün kütlesel veya hacimsel miktarının, } \\
\text { üretim işlemlerinde tüketilen enerji miktarına oranıdır. }\end{array}$ & Kütle (Hacim) /Enerji & $\operatorname{kg}(\mathrm{L})_{\text {ürün }} / \mathrm{MJ}$ \\
\hline & Enerji oranı & $\begin{array}{l}\text { Tarımsal üretim sonucunda elde edilen toplam ürün miktarının enerji eşdeğerinin, } \\
\text { üretim işlemlerinde doğrudan ve dolaylı olarak tüketilen toplam enerji miktarına } \\
\text { oranıdır. }\end{array}$ & Enerji/Enerji & $\mathrm{MJ} / \mathrm{MJ}$ \\
\hline \multirow{4}{*}{ 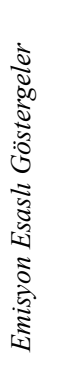 } & $\mathrm{CO}_{2}$ göstergesi & $\begin{array}{l}\text { Tarımsal üretim sonucunda elde edilen ürünün kütlesel veya hacimsel miktarının, } \\
\text { üretim işlemlerinde enerji tüketimi sonucunda gerçekleşen } \mathrm{CO}_{2} \text { emisyonlarının } \\
\text { toplam miktarına oranıdır. }\end{array}$ & Kütle/Kütle & $\mathrm{kg}(\mathrm{L})_{\text {ürün }} / \mathrm{kg}_{\mathrm{CO} 2}$ \\
\hline & $\mathrm{NO}_{2}$ göstergesi & $\begin{array}{l}\text { Tarımsal üretim sonucunda elde edilen ürünün kütlesel veya hacimsel miktarının, } \\
\text { üretim işlemlerinde enerji tüketimi sonucunda gerçekleşen } \mathrm{NO}_{2} \text { emisyonlarının } \\
\text { toplam miktarına oranıdır. }\end{array}$ & Kütle/Kütle & $\mathrm{kg}(\mathrm{L})_{\text {ürün }} / \mathrm{kg}_{\mathrm{NO} 2}$ \\
\hline & $\mathrm{SO}_{2}$ göstergesi & $\begin{array}{l}\text { Tarımsal üretim sonucunda elde edilen ürünün kütlesel veya hacimsel miktarının, } \\
\text { üretim işlemlerinde enerji tüketimi sonucunda gerçekleşen } \mathrm{SO}_{2} \text { emisyonlarının } \\
\text { toplam miktarına oranıdır. }\end{array}$ & Kütle/Kütle & $\mathrm{kg}(\mathrm{L})_{\text {ürün }} / \mathrm{kg}_{\mathrm{SO} 2}$ \\
\hline & $\begin{array}{l}\text { Toplam sera gazl } \\
\text { emisyonu göstergesi }\end{array}$ & $\begin{array}{l}\text { Tarımsal üretim sonucunda elde edilen ürünün kütlesel veya hacimsel miktarının, } \\
\text { üretim işlemlerinde enerji tüketimi sonucunda gerçekleşen sera gazı } \\
\text { emisyonlarının toplam miktarına oranıdır. }\end{array}$ & Kütle/Kütle & $\mathrm{kg}(\mathrm{L})_{\text {ürün }} / \mathrm{kg}_{\mathrm{CO} 2}$ \\
\hline
\end{tabular}

\section{Araştırma Sonuçları ve Tartışma}

\subsection{Tek Yıllık Bitkisel Üretimde Enerji Verimliliği Önlemleri}

Tarla bitkileri üretiminde, çoğu enerji tasarrufu önlemi gübreleme ve tarla uygulamalarıyla ilişkilidir. Bununla birlikte, tarla bitkileri üretiminde aşağıdaki uygulamalar gerçekleştirilerek de önemli düzeyde enerji tasarrufu sağlanabilir:

> Kurutma ve depolama gibi hasat sonrası uygulamalar

\section{$>$ Biyoaktif organizmaların uygulanması}

> Azaltılmış veya toprak işlemesiz tarımsal uygulamalar

> Enerji tüketimine ilişkin; denetleme-kontrol-veri toplama gibi bir izleme sisteminin uygulanması

Bitkisel üretimde enerji tasarrufu potansiyeli olan önlemlerin listesi Tablo.3'de verilmektedir. Bitkisel üretimde enerji tasarrufu potansiyeli yüksek olan başlıca önlemler arasında aşağıdaki uygulamalar yer alır:

> Toprak işleme ve diğer saha uygulamalarında yakıt 
kullanımını azaltmak

$>$ Tarla uygulamalarında traktör ve alet/makina kullanımını optimize etmek

$>$ Kurutma işleminde enerji tasarruflu ürün depoları kullanmak

$>$ Gelişmiş üretim yönetimleri uygulamak

Bitkisel üretimde dolaylı enerji tüketimini azaltarak enerji tasarrufu sağlayan başlıca önlemler şunlardır:

> Gelişmiş, yüksek verimli ve hastalığa dayanıklı çeşitler kullanmak

$>$ Organik/yeşil gübreler ve biyoaktif mikroorganizmalar gibi alternatif besin kaynakların ve bitki koruma yöntemleri uygulamak

> Üretim süreçlerini gelişmiş yöntemlerle izlemek

$>$ Toprak verimliliğine ve bitki besin elementi alımına uygun girdi kullanmak

Tablo 3. Tek Yıllık Bitkisel Üretimde Doğrudan ve Dolaylı Enerji Tüketiminde Enerji Verimliliği Să̆layan Önlemler

\begin{tabular}{|c|c|}
\hline Üretim Faktörü & $\begin{array}{l}\text { Doğrudan Enerji Tüketiminin } \\
\text { Azaltılması İçin Önlemler }\end{array}$ \\
\hline Toprak işleme & 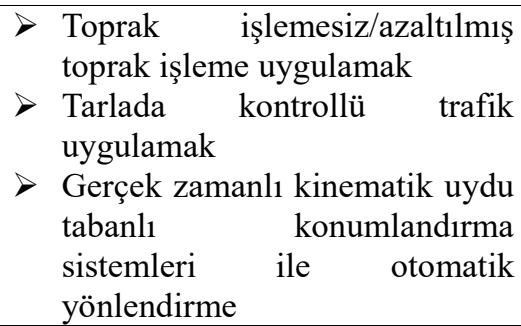 \\
\hline $\begin{array}{l}\text { Traktörler } \\
\text { alet/makinalar }\end{array}$ & $\begin{aligned} &> \text { Tarla uygulamaları ve taşıma } \\
& \text { için kullanılan traktör ve diğer } \\
& \text { alet/makinalar için güç } \\
& \text { optimizasyonu sağlamak } \\
&>\text { Lastik boyutları/basıncı ve ön } \\
& \text { aks ağırlığının uygunluğunu } \\
& \text { sağlamak } \\
&>\text { Ortak makina kullanımı } \\
&>\text { Üretimde kullanılan araçları } \\
& \text { birlikte kullanmak (alet/makina } \\
& \text { kombinasyonları) }\end{aligned}$ \\
\hline Üretim sistemi & $\begin{array}{l}>\text { Organik veya entegre üretimde } \\
\text { değişiklik yapmak } \\
>\quad \text { Hassas tarım uygulamak } \\
>\quad \text { Tarlada kontrollü uygulamak }\end{array}$ \\
\hline $\begin{array}{lr}\text { Kurutma ve } & \text { veplamada } \quad \text { isı } \\
\text { depolayılarını önlemek } & \text { kayıp }\end{array}$ & 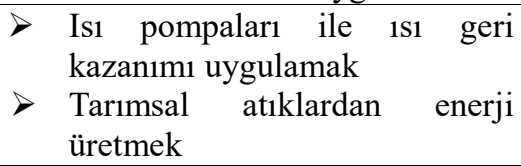 \\
\hline Diğerleri & $\begin{array}{l}\text { Enerji verimli işlem kontrolü } \\
\text { Yenilikçi kurutma ve depolama } \\
\text { sistemleri geliştirmek } \\
\text { Kurutma ve ürün depolama } \\
\text { tasarımlarının optimizasyonu } \\
\text { üzerine araştırmalar }\end{array}$ \\
\hline$\ddot{U}$ retim Faktörü & $\begin{array}{l}\text { Dolaylı Enerji Tüketiminin } \\
\text { Azaltılması İçin Önlemler }\end{array}$ \\
\hline Tohumlar/Yumrular & $\begin{array}{l}\text { Üretim birimi başına verim } \\
\text { potansiyeli yüksek ve daha } \\
\text { düşük enerji girdisi olan yeni } \\
\text { çeşitler kullanmak }\end{array}$ \\
\hline
\end{tabular}

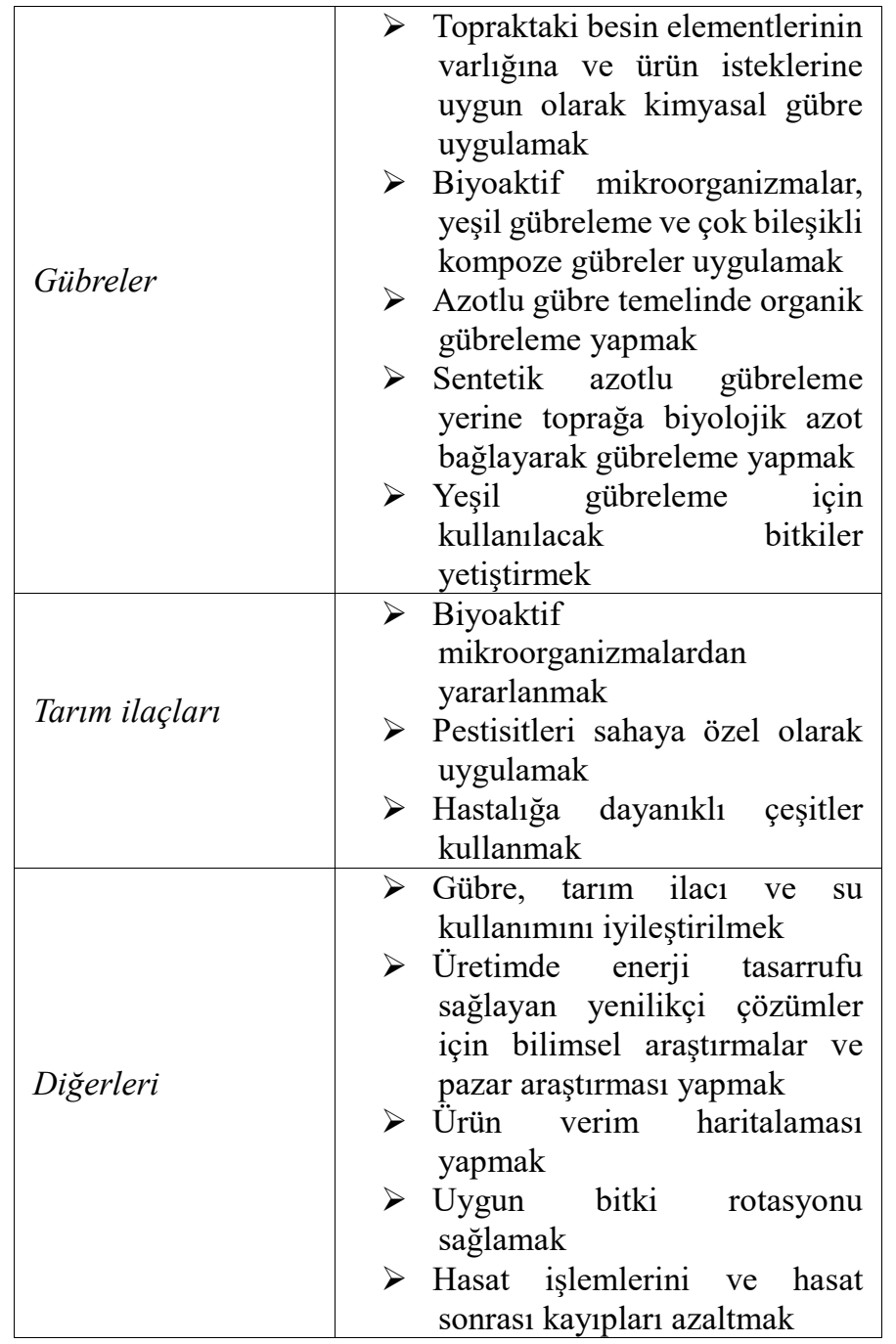

Enerji girdilerinden bağımsız olarak, sistem yenilikleri ile ilgili araştırmalardan da yüksek enerji tasarrufu potansiyeli beklenmektedir. $\mathrm{Bu}$ tür önlemler, işletimsel seviyeden daha yüksek ölçek düzeyindeki önlemlerdir. Tablo 3'de verilen enerji tasarrufu önlemleri bütün ülkeler için geçerli uygulamalardır. Bununla birlikte, enerji tasarrufu önlemlerinin, ülkeler arasında belirli bir üretim türü için toplam enerji tüketimi gibi önemli etmenler konusunda, daha güçlü veya daha zayıf etkileri olabilir.

Güney $\mathrm{AB}$ ülkelerinde, tahıl kurutması için enerji tüketimini azaltmak daha az önem arzederken, sulama uygulamalarında enerji tasarrufu daha önemli olabilecektir. (agrEE (2012a). Ayrıca, Yunanistan'daki pamuk üretimi gibi, ülkeye özgü bir ürün, enerji verimli damla sulama sistemleri ile su yönetimini geliştirmek için özel önem gerektirebilir (agrEE (2012a).

\section{2. Çok Yıllık Bitkisel Üretimde Enerji Verimliliği Önlemleri}

Üzüm ve zeytin gibi çok y1llık bitkisel üretimde, üretim süreçlerine bağlı olarak enerji tasarrufu önlemleri Tablo 4'de verilmektedir. Çok yıllık bitkisel üretimde ET önlemleri genel olarak aşağıdaki uygulamalar ile ilgilidir:

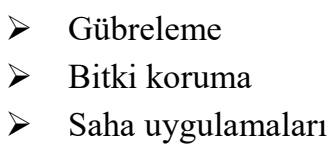

$>$ Gübreleme

$>$ Saha uygulamaları 
Tablo4. Çok Ylllık Bitkisel Üretimde Doğrudan ve Dolaylı Enerji Tüketiminde Enerji Verimliliği Sağlayan Önlemler

\begin{tabular}{|c|c|}
\hline Enerji Tüketimi & Enerji Tüketiminin Azaltılması İçin Önlemler \\
\hline $\begin{array}{l}\text { Doğrudan Enerji } \\
\text { Tüketimi }\end{array}$ & $\begin{array}{l}\text { Toprak işlemesiz üretim yapmak veya azaltılmış toprak işleme uygulamak } \\
\text { Zeytin ve üzüm hasat süreçlerinde taşıma/yükleme amaciyla kullanılan; yükleyiciler, kamyonlar } \\
\text { ve diğer makinalar için uygun güç optimizasyonu yapmak } \\
>\quad \text { Su ve toprak yönetimini iyileştirmek } \\
>\text { Enerji verimli pompalar kullanmak }\end{array}$ \\
\hline Dolaylı Enerji Tüketimi & $\begin{array}{l}>\text { Yüksek verim ve kaliteli bitkiler üretmek } \\
>\text { Kontrollü girdi uygulamaları ile kimyasal gübre ve tarım ilacı kullanımını azaltmak } \\
>\text { Organik gübre kullanımını artırmak } \\
>\text { Biyoaktif mikroorganizmaları uygulamak } \\
>\text { Uygulanacak gübre dozunu bölerek ve etkin olarak kullanım gibi uygulamalar ile esas olarak } \\
\text { azotlu gübreleme ile ilgili gelişmiş gübre yönetimi uygulamak }\end{array}$ \\
\hline
\end{tabular}

\section{Sonuç}

Bitkisel ve hayvansal üretimde başlica enerji tasarrufu önlemleri şunlardır:

> Kimyasal gübre ve tarım ilaçları dahil olmak üzere, tarımsal üretimdeki en büyük enerji girdilerini azaltmak

$>$ Traktörlere ve diğer makinelere güç sağlayan yakıtlar optimum düzeyde kullanmak

> Çiftlik binalarında ve tesislerinde isıtma, soğutma ve havalandırma için optimum düzeyde yakıt kullanmak

> Binalarda, ekipmanlarda, pompalamada ve aydınlatmada elektrik tüketimini azaltmak

Ar-Ge çalışmaları, üretim sürecinde yer alan sistemlere, işletimsel uygulamalara ve üretime giren sermaye malları/çiftlik altyapısına uygulandığında, tarımda enerji verimliliğgi sağlamak açısından önemlidir. Bitkisel üretimde enerji tasarrufu başlıca aşağıdaki etmenlere bağlıdır:

> Saha uygulamalarında traktör ve makine kullanımı ile ilgili değişkenleri optimize etmek

$>$ Kurutma ve ürün depolamada enerji kullanımını azaltmak

$>$ Dizel yakıt kullanımını azaltmak

Diğer taraftan, bitkisel üretimde dolaylı enerji tüketimleri aşağıdaki önlemler ile azaltılabilir:

> Gelişmiş yüksek verimli ve hastalığa dirençli çeşitlerle ilgili enerji tasarrufu önlemlerini uygulamak

$>$ Organik ve yeşil gübreler ve biyoaktif mikroorganizmalar gibi alternatif besin kaynakları ve bitki koruma yöntemlerinden yararlanmak

> Üretim süreçlerini gelişmiş teknolojik uygulamalar ile izlemek

$>$ Değişken oranlı hassas tarım uygulamaları gibi, üretimde kullanılan girdileri toprak verimliliği ve bitki besin alımına göre kullanmak

Enerji tasarrufu önlemlerinin önemi ülkelere özgü olabilir. Örneğin, güney $\mathrm{AB}$ ülkelerinde, tarımsal ürünlerin sulanması ile ilgili enerji tasarrufu önlemlerine, orta ve kuzeydoğu ülkelerinde ise, hasat edilen ürün için enerji verimli kurutma teknikleriyle ilişkili enerji tasarrufu önlemlerine daha fazla önem verilmektedir. Çok yıllık bitkisel üretimde enerji tasarrufu önlemlerinin çoğu; gübreleme, bitki koruma ve tarla uygulamaları ile bağlantılıdır.

\section{Kaynakça}

agrEE (2012a). State of the art on energy efficiency in agriculture. Country data on energy consumption in different agroproduction sectors in the European countries.

agrEE (2012b). Agriculture and energy effciency. Energy saving measures in agriculture-ovewiew on the basis of national reports. Agreement Number 289139.

Baran, M, Karaağaç, H, Mart, D, Bolat, A, Eren, Ö. (2019). Nohut Üretiminde Enerji Kullanım Etkinliği ve Sera Gazı (GHG) Emisyonunun Belirlenmesi (Adana ili örneği). Avrupa Bilim ve Teknoloji Dergisi , (16), 41-50 . DOI: $10.31590 /$ ejosat. 523080

Baran, M, Karağaç, H, Bolat, A, Çil, A, Çil, A. (2019). Yerfistığı Üretiminde Enerji Kullanım Etkinliğinin Belirlenmesi (Adana ili örneği) . Avrupa Bilim ve Teknoloji Dergisi , (15) , 103-111 . DOI: 10.31590/ejosat.501576.

Baran, M, Gökdoğan, O. (2020). Determination of Energy Balance in Pumpkin Seed (Cucurbita pepo L.) Production. Avrupa Bilim ve Teknoloji Dergisi , (19), 43-47 . DOI: 10.31590/ejosat. 715740

Yildızhan, H . (2019). Portakal Üretim Sürecinin Termodinamik Değerlendirilmesi; Yeni Bir Yaklaşım . Avrupa Bilim ve Teknoloji Dergisi , (15) , 96-102 . DOI: 10.31590/ejosat.521449

Pelletier, N, Audsley, E, Brodt, S, Garnett, T, Henrikkson, P, Kendall, A, Kramer, K, Murphy, D, Nemecek, T, Troell, M, (2011). Energy intensity of agriculture and food systems. Annual Review of Environment and Resources 36, 233-246.

Woods, J, Williams, A, Hughes, JK, Black, M, Murphy, R. (2010). Energy and the food system. Philosophical Transactions of the Royal Society B: Biological Sciences 365 (1554), 2991-3006. 